\title{
Det strålande solskenets översikt
}

\author{
Götsangrepas katalog över Tsangnyön \\ Herukas sångsamling
}

Namo guru dewa ḍakini!

Denna text innehåller en översiktlig förteckning över den vördade Tsangpa Herukas sånger, han som är den store segerrike Vajradharas högsta emanation och har många namn. Texten bär namnet Det strålande solskenet.

Medan Tsangnyön utövade kraftfull disciplin vistades han på, och vandrade runt bland, heliga platser och begravningsplatser. När han kom till Tagdong Tramo i Lachi för första gången och utövade till gagn för alla, uttryckte han den insikt som uppstått inom honom i den storslagna sången "Den stora farkostens verkliga mening".

Andra gången han kom till Lachi och stannade i Chomronggrottan, gav han instruktioner till hjärtesonen Rinchen Palsang i den storslagna sången "Löftet om att vårda, befria och bringa de lyckosamma lärjungarna till mognad". I ett därpå följande avsnitt med frågor och svar återfinns sånger med svar på denne hjärtesons frågor.

När Tsangnyön vistades på en plats för utövning kallad Fotavtryckets grotta gav han instruktioner till den gudomlige prinsen Samdrub De. Han sjöng då den storslagna sången "Att vederlägga felaktig argumentation och visa hur tillkortakommanden i själva verket kan vara goda egenskaper”. Efter detta sjöng han en sång med korta svar på Samdrub Des frågor.

Därefter sjöng Tsangnyön den storslagna sången ”Jaglöshetens lejon, rytandet som uttrycker den yttersta meningen, vederlägger felaktiga synsätt och underkuvar den lägre farkostens anhängare”.

När Tsangnyön vistades i Mangyul Kökardrag gav han instruk- 
tioner till Shengom Dorje Nyingpo i sången "En introduktion till den djupa meningen".

Därpå gav Tsangnyön instruktioner till fadern, konungen (Namgyel De), i sången "En uppfordran som avslöjar tillkortakommanden".

Under vistelsen i Det klara ljusets grotta i Ron sjöng Tsangnyön en sång med svar på prinsessan Dzamling och Khandro Sangmos frågor.

Därefter skrev han ner en sång med instruktioner till härskarinnan Sönam Sangmo.

Sedan reste Tsangnyön till Gungtangs huvudstad och sjöng där en sång med instruktioner till sin hjärteson Möndze Togden inför hans resa till Kailash.

Efter detta skrev Tsangnyön ner sånger med svar på frågor i två brev till sin hjärteson Sönam Drubpa och till den fullt ordinerade munken Namlegpa (Namka Gyaltsen).

I Maitreyatemplet i Nyānang gav han instruktioner till yogin Palden Sangpo i en sång där utövningen beskrivs med hjälp av fula ord.

Då Tsangnyön för tredje gången åter besökte Lachi och stannade ovanför Tserleb, svarade han på hjärtesonen Jigme Drakpas frågor i den storslagna sång som förklarar drömmars mening och förutsäger den spontana aktivitet och nytta för de kännande varelserna som ska uppstå i framtiden.

Därefter gav han instruktioner till Döndrub Rabsel från Kharkha i sången om de två meningarna - den tillfälliga och den slutgiltiga.

När Tsangnyön senare besökte den mycket heliga platsen Tsari, det tredje visdomshjulet, och vistades i Tashi Gesharma i övre delarna av Tsari samt i Tsangpa Pangchung, sjöng han den storslagna vajrasången, dohān "Insikten om den yttersta meningens åska - en introduktion till mahāmudrās synsätt, meditation, uppförande och resultat".

När Tsangnyön vistades i Kristallgrottan och tryckte upp den vördade Milas samlade verk sjöng han en sång till hjärtesonen Rinchen Palsang med instruktioner att bära med sig under resan till Tsari.

Under den period som varade från och med Tsangnyöns senare vistelse i Lachi och fram till hans femte vistelse i Tserleb svarade Tsangnyön på modern Kuntu Sangmos frågor i flera sånger. Han sjöng en sång som frammanar uppmärksamhet, en sång som introducerar uppbyggandets och fullbordandets meditationsfaser, samt en sång som visar hur man ska utöva under meditationsperioderna 
och under postmeditationsperioderna. Denna sång förklarar också begreppen orsak och verkan.

När Tsangnyön vistades i den mycket ensligt belägna eremitboningen Ganden som ligger i nirmāṇakāyapalatset Chuwar, gav han dharmainstruktioner inför en resa till hjärtesonen Chöchok Palsang, i en sång om hur man styr landet.

Vid ett annat tillfälle sjöng han en sång som sammanfattar stadierna och vägarna som svar på Möndze Togdens fråga.

När han senare reste till Kailash sjöng han en sång med instruktioner till kung Sherab Palsang i Gungtang.

Under samma resa till Kailash sjöng han en sång med instruktioner till härskarinnan av Menkab.

Därefter vistades han i Chuwar och reste sedan till Nepal. I Svayambhū gav han instruktioner till Lopön Jetsun i en sång som bestod av fyra vajrastrofer.

När han anlände till Lajang, vid Nepals gränsområde, sjöng han "Maṇisången" som handlar om hur Genyen Shentaputri bett honom renovera Svayambhū.

Efter detta reste Tsangnyön till Lhasa, centrala Tibets dharmahjul. När han kom till Nyetang undervisade han dharmakungen Dönyö Dorje i en sång som visar hur man upprättar rättfärdiga lagar som är i samklang med läran. Han stödde sig på kapitlet Den gudomliga härskaren från Det sublima gyllene ljuset, sūtrornas konung när han gjorde detta.

Tsangnyön uttalade sina sista vajrafraser då han lät sin nirmāṇakāya upplösas i rymden. Detta skedde i Rechungpuk i Yarlung.

Tsangnyön sjöng tjugoen sånger med muntliga instruktioner och sex storslagna välkända sånger. Tillsammans blir det tjugosju instruktioner i form av sånger bestående av auktoritativa vajraord.

Denna katalog ger en översikt över vajrasångerna. Den sammanställdes för att klargöra vajrayāna och bär namnet Det strålande solskenet. Dessa vajrasångers hemliga ord kommer från den store Vajradhara och sammanställdes av ljusgnistan, Götsangrepa, som följer ljusets källa, solen. ${ }^{314}$

Må alla varelser uppnå Vajradharas tillstånd.

Evam! 